\title{
Unregulated Markets for Audit Services
}

\author{
KARIM JAMAL \\ School of Business \\ UNIVERSITY OF ALBERTA
}

\author{
Shyam Sunder* \\ School of Management \\ YALE UNIVERSITY
}

\begin{abstract}
Certification of financial reports is tightly regulated with the intent to ensure the quality of this service. In order to place this market within a larger perspective, Part I of this paper presents archival data on certification activity in the economy. The finding of widespread availability of a diverse set of certifiers for most goods and services points to the competitive conditions that accounting firms may encounter as they attempt to expand their range of services. In Part II we examine an instance of audit firms unsuccessfully competing with non-traditional assurance providers of e-commerce privacy certification. Their failure appears to be attributable, at least in part, to the high cost of certification, inferior standards, and poor compliance by their clients. In Part III we document the types of certification reports issued by government agencies and private certification services. Private certification agencies issue more detailed and informative certification reports compared to government agencies. We discuss the implications of these findings for the market for audit services.
\end{abstract}

JEL Classifications: M49; G34; G38

Key Words: Private Audit; Regulation; Certification Services; Audit Reports

\section{Introduction}

The auditing of financial reports is tightly regulated in all developed countries. The market for audit services has matured; such services have become a commodity characterized by falling prices, declining margins, and little growth (Elliott 1995, 1998). This has spurred audit firms to expand the scope of their services to broader "assurance" markets. They have also attempted to create a new designation to signal and legitimize a broader role for their profession (Covaleski et al., 2003). We explore how markets for certification services function in absence of regulatory mandates.

\footnotetext{
* Corresponding Author. Address Yale School of Management, 135 Prospect Street, New Haven, CT 06511, USA.

Telephone+1 203-432-6160 E-mail shyam.sunder@yale.edu.
} 
When audit firms seek to sell additional services to their audit clients, concerns about the audit firms' independence arise. Accounting firms can grow by expanding into services that are not perceived to be incompatible with their role as financial auditors, e.g., corporate social responsibility audits. Better yet, they could try to sell financial audit services in new markets, such as Russia and Eastern Europe (Mennicken 2010). Expanding into unrelated fields in which they have little expertise is a more complicated and risky move. The WebTrust seal of privacy and security for corporate websites is a recent example of such a move. Upon entering what they may believe to be virgin territory without adequate knowledge and understanding, audit firms may be surprised, frustrated, and even defeated by a variety of entrenched professional and non-professional competitors. In this paper, we examine unregulated certification services in the economy to provide some evidence about the competitive conditions that audit firms might find in such markets.

Michael Power draws attention to the expansion of the scope of certification services, calling it "an audit explosion" in society (Power 1994, 1999). The demand for certification is usually believed to be driven by the need to control agency costs (Antle 1984), or by shifts in regulatory demand for better accountability and control (Radcliffe 1998). However, our research suggests the possibility that at least a large part of the demand for certification is private, personal, and mundane, pervading all sectors of the economy. Certification is routinely demanded (and supplied) for baseball cards, toasters, and washing machines in markets that lack organizational relationships or government regulation. Changes in information technology have made it easier to access opinions of traditional experts as well as a host of non-professional expert and peer opinions. Demand for most kinds of certification seems to arise from their information value, not from concerns relating to enforcement of accountability.

We use "certification" in its broad meaning of "the act of giving assurance of quality or validity," in the sense conveyed by terms such as corroboration, verification, validation, measurement and guarantee. ${ }^{1}$ The present study compares examples of certification services in unregulated markets across sectors of the economy. The WebTrust seal of privacy and security for corporate websites is a good example of auditors' attempts to compete in a non-traditional market. Since this product was designed to appeal to the retail visitors to the websites of corporate clients, its features are publicly observable, obviating the need for expert judges to ascertain independently their quality.

Competition can also influence the nature of audit reports. Lizzeri's (1999) model indicates that a monopolist certifier provides coarsely graded "pass/fail" reports whereas competition in the certification market leads to the provision of more informative reports. The Dubey and Geanakoplos (2010; henceforth DG) model indicates that an optimal grading scheme should have an intermediate level of fineness, an elite grade for a few, and an absolute rather than relative grading scheme. The elite grade motivates high-ability clients to exert effort; the absolute grading scheme motivates clients of medium skill to exert effort; and the intermediate level of fineness balances measurement error with the limited capacity of users to process grade differentiation.

The present study has three parts. In Part 1, we report data on the types and ubiquity of certification services available in the economy. We select a representative sample of private goods (chosen from the producer and consumer price indices published by the government and from eBay), and search for certification services available for each. In Part 2, we assess and compare the certification standards for internet privacy developed by WebTrust in the accounting profession with those developed by the non-accounting competitors. We also compare the privacy practices of websites certified by WebTrust and by non-accounting certification agencies. In Part 3, we compare certification by government and private agencies. We find that: (1) there is large and

1 This broad usage of audit as a monitoring technology extends beyond the narrower usage prevalent in the context of financial reporting (Power 1994). 
widespread private supply (and, therefore presumably, demand) for certification services in virtually all parts of the economy, both online and offline, and receptive to both professional and nonprofessional providers; (2) accounting firms who ventured into e-commerce privacy certification had weaker standards, as well as weaker compliance with those standards, compared to their nonprofessional competitors; (3) fineness of grading scales used by private certification agencies are used as instruments of competition, and they are consistent with one of the three predictions of the DG model. Government agencies on the other hand, generally provide pass/fail reports consistent with the prediction of Lizzeri (1999). We return to these issues in concluding remarks.

\section{Part I: Demand for Certification Services and Competition in the Broader Economy}

In Part 1, we document the explosion of audit services (Power 1994) in the unregulated sector. We selected a sample of 817 items sold online and offline. Goods sold online were selected from eBay.com (400 items, chosen at the category level used by eBay). The "all categories" page on eBay listed all the items available for sale in 31 main categories and a hierarchical structure organizing thousands of items under layers of subcategories. We selected all items at the first subcategory level (e.g., sports cards) resulting in a sample of 400 items, excluding catch-all subcategories such as "other." Goods sold offline were selected from the U.S. Producer Price Index (PPI - 358 items) and Consumer Price Index (CPI - 59 items), as published by the U.S. Bureau of Labor Statistics (www.bls.gov). The PPI has a hierarchical structure with 15 main categories. We selected a sample of all items at the second subcategory level, resulting in a sample of 358 items. The CPI has a flatter hierarchical structure, and in some cases there are no subcategories (e.g., college textbooks). We chose all unique items in the CPI that were not in the PPI sample.

Of the variety of certification services available for goods and services in the private economy, the most formal and traditional service is the offer of an expert opinion on compliance with the relevant formal written standards. This is also the option most favored by the accounting profession, and accountants are discouraged from offering opinions in the absence of written standards. It is also possible to obtain expert opinions in the absence of a formal set of standards, laypersons' ratings without formal standards, and a variety of audience/popularity meters that simply record the level or rank of activity (e.g., bestseller book, music, and film lists).

Panel A of Table 1 indicates that out of the 817 goods in the sample, we were able to find experts who would provide a certification with compliance to a formal set of standards for 743 of the goods (91\%). For another 59 goods (7\%), we were able to find experts who would provide an opinion, but without use of a formal set of standards (e.g., to rate sculptures, antiques, paintings, and gardening services). Among the remaining items, we were able to find laypersons' ratings for 8 (1\%), and a meter for $3(0.5 \%)$. We were unable to find any kind of certification service for only 4 items (0.5\%, e.g., parking services, tattoos, other body art, and sale of coupons). Overall, for 813 or $99.5 \%$ of the goods in our sample, it was possible to find some kind of certification service.

Panel B of Table 1 provides the available combinations of certification services. For 322 items ( $40 \%$ of the sample) the full range of certification services was available: standards with expert opinion, expert opinion only with no formal standards, lay opinion, and meter. For 114 items (14\% of the sample), only an expert opinion using a formal set of standards was available. For all the remaining items, more than one kind of certification was available.

These findings support Power's (1994) characterization of our civilization as an "audit society." 
Table 1: Certification Services for Products Sold Online and Offline in the Us

\begin{tabular}{lrrrr}
\hline \hline Panel A: Four Levels of Certification Activity & & & & \\
\hline & $\begin{array}{c}\text { EBay } \\
\mathbf{N = 4 0 0 )}\end{array}$ & $\begin{array}{c}\text { PPI/CPI } \\
\mathbf{( N = 4 1 7 )}\end{array}$ & $\begin{array}{c}\text { Total } \\
\mathbf{( N = 8 1 7 )}\end{array}$ & $\begin{array}{c}\text { \% of } \\
\text { Total } \\
\mathbf{( 8 1 7 )}\end{array}$ \\
\hline Expert Opinions Based on Written Standards & 344 & 399 & 743 & $91 \%$ \\
\hline Expert Opinions Without Written Standards & 45 & 14 & 59 & $7 \%$ \\
\hline Lay People Ratings & 5 & 3 & 8 & $1 \%$ \\
\hline Meter & 3 & 0 & 3 & $0.5 \%$ \\
\hline No Certification / Rating & 3 & 1 & 4 & $0.5 \%$ \\
\hline
\end{tabular}

Panel B: Breakdown of Certification Activities

All Certification Available (Expert Opinions Based on

Written Standards, Expert Opinions Without Written

Standards, Lay People Ratings, and Meters)

\begin{tabular}{lcccc}
\hline Expert Opinions Based on Written Standards only & 4 & 110 & 114 & $14 \%$ \\
\hline $\begin{array}{l}\text { Expert Opinions Based on Written Standards, Lay People } \\
\text { Ratings and Meter }\end{array}$ & 33 & 57 & 90 & $11 \%$ \\
\hline $\begin{array}{l}\text { Expert Opinions Based on Written Standards and Expert } \\
\text { Opinions Without Written Standards }\end{array}$ & 47 & 34 & 81 & $10 \%$ \\
\hline $\begin{array}{l}\text { Expert Opinions Based on Written Standards, Expert } \\
\text { Opinions Without Written Standards, and Lay People } \\
\text { Ratings }\end{array}$ & 17 & 34 & 51 & $6 \%$ \\
\hline Expert Opinions Based on Written Standards, and Meter & 8 & 28 & 36 & $4 \%$ \\
\hline $\begin{array}{l}\text { Expert Opinions Based on Written Standards, Expert } \\
\text { Opinions Without Written Standards, and Meter }\end{array}$ & 11 & 15 & 26 & $3 \%$ \\
\hline $\begin{array}{l}\text { Expert Opinions Based on Written Standards, and Lay } \\
\text { People Ratings }\end{array}$ & 3 & 20 & 23 & $3 \%$ \\
\hline All other combinations & 56 & 18 & 74 & $9 \%$ \\
\hline
\end{tabular}

Note: 400 goods sold on eBay and 417 goods included in the U.S. CPI and PPI (www.bls.gov) were selected. We then searched for the existence of written standards, expert opinions based on written standards (e.g., Michelin guide rating of restaurants), expert opinions that are not based on any written standards (e.g., New York Times Food Critic Rating of restaurants), lay people ratings (on various websites), and meters recording level of activity (e.g., revenue of a restaurant, or reservation time to get into a restaurant) which people can use to infer quality and/or popularity of a product. These results are summarized in panel A. The panel A results indicate that for $91 \%$ of the goods in our sample, we were able to find an expert opinion based on written standards. For the remaining $9 \%$, we were able to find an expert opinion but without reference to any written standards (7\%), lay people rating (1\%), a meter $(0.5 \%)$ or no certification of any kind (0.5\%).

For many goods, multiple forms of certification are available; in some cases everything from expert opinions based on written standards, expert opinions which are not based on any written standards, lay people ratings, and even meters recording level of activity. In panel B, we summarize the different forms of certification available for goods in our sample. The Panel B combinations are presented in order of their frequency. The most frequent combination (occurring $40 \%$ of the time) is to have all forms of certification available (Expert Opinions Based on Written Standards, Expert Opinions Without Written Standards, Lay People Ratings, and Meters).

He focused on how audit firms and/or governments seek to make a variety of entities "auditable." Our results suggest that the process of making things auditable is a general phenomenon and is pervasive throughout the economy. Even in the most mundane economic activity (e.g., buying a toaster), a consumer can get one or more types of certification.

In the accounting literature, a recurring theme is the importance of establishing an aura of 
Table 2: Qualifications of Experts Providing Opinions on XYZ Website

\begin{tabular}{|c|c|c|c|c|}
\hline & Accreditation & Education & Business & Hobby \\
\hline 1. Art and Antiquities $(n=14)$ & $64 \%$ & $50 \%$ & $71 \%$ & $7 \%$ \\
\hline 2. Books, Maps, Manuscripts $(\mathrm{n}=5)$ & $20 \%$ & $20 \%$ & $80 \%$ & $20 \%$ \\
\hline 3. Clocks, Watches and Timepieces $(n=4)$ & $25 \%$ & $25 \%$ & $100 \%$ & $0 \%$ \\
\hline 4. Clothing, Linens, Rugs and Quilts $(n=6)$ & $33 \%$ & $17 \%$ & $100 \%$ & $0 \%$ \\
\hline 5. Coins, Stamps, Numismatics $(\mathrm{n}=7)$ & $29 \%$ & $14 \%$ & $100 \%$ & $0 \%$ \\
\hline 6. Electronics $(n=3)$ & $33 \%$ & $0 \%$ & $67 \%$ & $33 \%$ \\
\hline 7. Famous People $(n=4)$ & $25 \%$ & $0 \%$ & $100 \%$ & $0 \%$ \\
\hline 8. Furniture and Accessories $(n=8)$ & $50 \%$ & $0 \%$ & $75 \%$ & $13 \%$ \\
\hline 9. Glass $(n=5)$ & $40 \%$ & $20 \%$ & $100 \%$ & $0 \%$ \\
\hline 10. Guns, Knives and Swords $(n=5)$ & $60 \%$ & $0 \%$ & $100 \%$ & $0 \%$ \\
\hline 11. Jewelry $(\mathrm{n}=6)$ & $50 \%$ & $33 \%$ & $83 \%$ & $0 \%$ \\
\hline 12. Knick Knacks and Collectibles $(n=7)$ & $14 \%$ & $28 \%$ & $86 \%$ & $0 \%$ \\
\hline 13. Music ( $\mathrm{n}=4)$ & $25 \%$ & $25 \%$ & $75 \%$ & $0 \%$ \\
\hline 14. Nature's Treasures $(n=1)$ & $0 \%$ & $100 \%$ & $100 \%$ & $0 \%$ \\
\hline 15. Photography, Cameras, Projectors $(n=3)$ & $33 \%$ & $67 \%$ & $67 \%$ & $33 \%$ \\
\hline 16. Porcelain, Ceramic and Pottery $(n=10)$ & $50 \%$ & $20 \%$ & $60 \%$ & $20 \%$ \\
\hline 17. Silver $(\mathrm{n}=7)$ & $43 \%$ & $29 \%$ & $71 \%$ & $14 \%$ \\
\hline 18. Sports $(n=6)$ & $17 \%$ & $17 \%$ & $67 \%$ & $33 \%$ \\
\hline 19. Tools, Kitchenware \& Equipment $(n=3)$ & $33 \%$ & $0 \%$ & $100 \%$ & $0 \%$ \\
\hline 20. Toys, Dolls, Games ( $\mathrm{n}=9)$ & $44 \%$ & $11 \%$ & $78 \%$ & $0 \%$ \\
\hline 21. Transportation $(n=4)$ & $25 \%$ & $25 \%$ & $25 \%$ & $25 \%$ \\
\hline 22. Wine $(n=2)$ & $50 \%$ & $50 \%$ & $50 \%$ & $0 \%$ \\
\hline 23. General Appraisers (other) $(n=6)$ & $33 \%$ & $67 \%$ & $83 \%$ & $17 \%$ \\
\hline Total $(n=128)$ & $50(39 \%)$ & $32(25 \%)$ & $101(79 \%)$ & $12(9 \%)$ \\
\hline
\end{tabular}

Note: A site we call XYZ is an official partner of eBay and has 128 experts who offer opinions on 1,850 separate items for a fee of $\$ 9.95$ (basic service) or $\$ 29.95$ (enhanced service). The site provides a description of some of its experts. Data in this table on accreditation, education, and business interests of experts were obtained from XYZ and reflects attributes of competence of all experts providing opinions on the site. As far as we know, these are self-assessments of competencies with no independent verification that we are aware of. Most of the experts who provide an opinion on this site (79\%) also run a related business (e.g., the wine expert owns a wine shop, and the carpet expert owns a carpet shop).

expertise and legitimacy through professional associations. Powerful lobbies representing accountants and other professionals interact with state regulators in order to influence the terms of entry to the profession (Cooper and Robson 2006, Gendron et al., 2007). However, the results presented in Table 1 suggest that the markets for expert certification are more flexible in accepting claims of various kinds of expertise. While a restaurant certifier like Zagat may have many of the attributes of an audit firm (written standards, a certification process, standardized report), the markets are also willing to use self-appointed experts who do not issue standard reports (e.g., a New York Times restaurant critic) or even laypersons' reports of their personal, idiosyncratic experiences in restaurants.

For additional evidence on individuals' willingness to carry out transactions with certifiers of varying degrees of expertise, we approached a website (which we call ABC) for information about the panel of experts whose opinions are made available on the Internet. ABC is an official partner of eBay and has 128 experts who offer opinions on 1,850 items for a fee of $\$ 9.95$ (basic service) or $\$ 29.95$ (enhanced service) per assessment. These experts do not follow any written standards, nor are 
their opinions based on reference to standards. For some of its experts, the site provides a description, educational background, relevant business and other experience, and, in some cases, accreditation by professional bodies.

Since the list of $\mathrm{ABC}$ experts is rotated periodically, we could not be sure that all their experts were listed at any given time. We obtained data on accreditation, education, and business interests of all listed experts available to provide opinions on the site (see Table 2). Of the 128 experts, 50 (39\%) held formal accreditation from a professional body; 32 (25\%) had relevant educational credentials (e.g., opinions on art being offered by persons having an advanced degree in art history); and 101 (79\%) ran a business involved in the activity they were providing opinions on (e.g., a carpet shop or a wine store). Only 12 experts (9\%) did not report any formal credentials and indicated that they were hobbyists interested in activity on which they opined.

\section{Implications for Auditing}

The accounting profession has tried to create a professional identity by requiring its members to develop written standards and then issue a report certifying their client's compliance with those written standards. This gives accounting firms a distinct but not unique identity. For about $91 \%$ of the private goods in our sample, we document the presence of certification agents with similar profiles of having written standards, an audit process and standardized reports. However, nonaccountant competitors may also operate with and without written standards, and with and without formal credentials. The accounting profession has recently added a 5 th year of schooling required for becoming a CPA in the U.S., and similar proposals are being considered in other countries, such as Canada. Our findings call for more research on the value of formal credentials in certification markets.

\section{Part II: Provision of WebTrust Privacy Certification}

Accountants usually respect as credible other professional competitors, such as lawyers who compete for work in established accounting markets (e.g., for provision of tax services). Lawyers have all the professional attributes valued by accountants, including formal education, an examination process, a codified body of knowledge, and an elaborate code of ethics. One explicit argument for creating a new, international XYZ professional designation was the desire to expand the zone of market permission (legitimacy) to broaden the range of services that accounting professionals could offer (Elliott 1995, Covaleski et al., 2003).

Accountants tend to be dismissive of non-traditional competitors, however, viewing them as providers of lower quality services (see, for example, responses of accountants in the Gendron and Barrett 2004 study of web assurance services). Yet, these non-traditional competitors dominate accountants in non-accounting markets (see market shares documented in Part I). Failure to expand into markets for web assurance services is a good example of the consequences of accountants not understanding this non-traditional competition.

In 1997, the American Institute of Certified Public Accountants (AICPA) and the Canadian Institute of Chartered Accountants (CICA) jointly introduced a service called WebTrust, intended as a marquee product for accountants wanting to provide high-value assurance services in the new economy. Yet, despite the full institutional marketing muscle of large networks of the AICPA and CICA, WebTrust was a commercial failure. WebTrust faced competition from a consortiumsponsored privacy certifier called TRUSTe, and a certifier sponsored by the Better Business Bureau 
(BBB Online). Despite various claims by accountants that their standards and services were superior, the market favoured their non-accountant competitors.

A study of e-commerce privacy practices by Jamal, Maier, and Sunder (2003, henceforth JMS) showed that, of the 500 most-used websites in the US, not a single site had a WebTrust seal. In addition, two Big Five accounting firms-PricewaterhouseCoopers and Ernst and Young-defected from the accounting profession's common marketing effort, and developed competing seals based on their own proprietary standards (PWC's BetterWeb and EY's CyberProcessor Certification). Both these firms also sponsored competing web seals such as TRUSTe, which had 2,000 clients as of the summer of 2001 (Jamal, Maier and Sunder 2003, 2005).

Members of AICPA and CICA, and accounting firms participating in the WebTrust program were puzzled by their failure, bitter at the firms for breaking rank, and generally unsure about what to do next (Gendron and Barrett, 2004). AICPA and CICA continued to revise WebTrust standards to make it more attractive. WebTrust 1.0 (issued in 1997) focused heavily on the authentication of businesses and security and was replaced by WebTrust 2.0. In 2000 AICPA and CICA issued WebTrust 3.0 to break the service into modules, including a new privacy assurance module. Since AICPA was convinced that its WebTrust service was superior to that of its competitors, it attributed its poor performance to the higher prices charged for its service. WebTrust's Module 3 sought to address pricing pressure by selling individual modules that could be packaged to serve the customized needs of specific clients at a lower price. However Module 3 also failed in the marketplace.

It is easy for accountants to deride TRUSTe and BBB Online, because neither entity conducts manual audits. Instead, they review their clients' posted privacy policies and pose as customers to "audit" the customer experience in visiting and using the sites. They also rely on customer complaints to police the clients. While this may seem to be a weak enforcement mechanism, compliance with their disclosure standards is remarkably high. In a study of privacy policies, JMS programmed a web crawler to visit 100 high-traffic websites and record the cookies (small text files on a visitor's hard drive that allow the website to recognize a user) used by each site. ${ }^{2}$ TRUSTe and BBB Online privacy policies require disclosure of tracking mechanisms, such as cookies, used by websites, and especially require disclosure of third-party cookies popular with online advertisers such as Doubleclick, which aggregate data from hundreds of websites to create user profiles for marketing purposes.

JMS found that $100 \%$ of websites with a privacy seal from TRUSTe or BBB Online had a posted privacy policy that was easy to find. All these sites disclosed their use of cookies; $88 \%$ explained what cookies are and what information they collect; and 56\% even explained how to turn off or monitor the cookies. Almost all of the sites that used third-party cookies (97\%) disclosed their practices, and $63 \%$ provided a link to the privacy policy of the third party or a link to opt-out of the third-party cookie. This rate of compliance is remarkably high, and significantly better than websites with similar traffic volume that did not have a web seal (see also Jamal, Maier and Sunder 2005 for the effect of EU privacy law in the UK).

The high quality of privacy policies and actual disclosure practices by TRUSTe and BBB Online clients suggests there is little room for accounting firms to develop superior privacy-disclosure standards or compliance practices. JMS also sent their web crawler to 20 randomly chosen WebTrust clients and 20 randomly chosen PWC BetterWeb clients. ${ }^{3}$ Disclosure of cookie usage was good (85\% for WebTrust clients, $95 \%$ for PWC clients), though none of their clients disclosed the presence

\footnotetext{
${ }^{2}$ If you $\log$ onto a site and the site remembers your password, or greets you by name, then the site is using a cookie to recognize you 3 These data were collected and reported in an early working paper by Jamal, Maier, and Sunder, but were removed during the review process and were not reported in the published JMS (2003) paper.
} 
of third-party cookies on their website. WebTrust and PWC standards do not require disclosure of third-party cookie usage, and their clients don't provide such disclosures. More than 50\% of WebTrust (and PWC) clients did not even allow users to opt-out of receiving commercial messages from the website. On average, privacy disclosures and opt-out practices of accounting firm clients are poorer than those of TRUSTe and BBB Online clients. WebTrust's privacy module and the practices of websites with a WebTrust seal appear not to be at the cutting edge of privacy practices. WebTrust is a follower, not a leader in setting new privacy standards and appears not to have an effective compliance mechanism.

In 2011 the AICPA/CICA alliance is still developing a new privacy framework and issued a new privacy maturity model (PMM) on March 11, 2011 (see www.aicpa.org/privacy). There is no indication that the accounting profession has understood how to compete with non-accounting competitors in the web privacy market. The accounting profession is also seeking to create new markets for certifying corporate social responsibility activities, though we know of no index that can be used to assess their success in providing quality standards or assurance in this non-accounting domain.

\section{Part III: Developing a Reputation for Audit Quality via Fineness of Audit Reports}

No matter how thorough and effective the auditor is, he labours in vain if he cannot clearly convey the results of his efforts in a useful form to those who need to know them.

American Accounting Association, A Statement of Basic Auditing Concepts, (1973).

Providing informative and accurate audit reports is an obvious means of building a reputation for audit quality among the users of financial statements (DeAngelo, 1981). In the course of his work, an auditor develops a detailed understanding of the quality of a company's internal control system, governance, accounting policies, estimates, and disclosure. Yet, the standard audit reports currently issued are, for all practical purposes, pass $/$ fail,${ }^{4}$ and they convey a bare minimum of the auditor's detailed understanding about the company to the shareholders. Indeed, Lizzeri's economic model (1999) predicts that a monopolist certifier will produce low precision pass/fail reports, whereas a certifier facing more competition will issue more precise (finer) reports. A coarser system also induces managers of clients to disclose to the auditors only the minimum necessary to get a pass grade. ${ }^{5}$

The 2010 DG model of grading schemes suggests that a coarse (pass/fail) grading scheme conveys less information and induces less motivation for agents to exert effort to raise performance. A fine grading scheme introduces measurement error and discourages agents with intermediate levels of talent. An intermediate level of fineness, e.g., a 3- or 10-point system, balances these two considerations by providing useful information and motivating agents to work harder. The DG model also suggests that the optimal grading scheme should create a small elite grade (i.e., a hard-to-get A), and that an absolute grading scheme (e.g., a score of more than 85 percent is an A) should strictly

\footnotetext{
4 "The report shall state whether the financial statements are presented in accordance with generally accepted accounting principles (GAAP).... The report shall contain either an expression of opinion regarding the financial statements, taken as a whole, or an assertion to the effect that an opinion cannot be expressed." (http://www.pcaobus.org/standards/interim_standards/ auditing_standards/index_au.asp?series=100\&section=110). Auditors are expected to add details when the report is "fail."

5 Blackwell's fineness condition suggests that, in a game against nature, a finer report would be more useful to shareholders. Since the subjects of audit/grading are active agents, it is not useful to think of the process as a game against nature.
} 
dominate grading on a curve. The elite grade motivates high-talent certifiers, whereas an absolute grading scheme motivates certifiers of intermediate talent.

We collected data on the fineness of government rating standards by visiting the websites of 80 federal government departments listed as having a standard-setting function in the most recent edition of the U.S. government publication entitled "Standards Activities of Organizations in the United States" (Toth, 1996). We succeeded in downloading electronic copies of standards for 64 agencies (80\%). We recorded a summary of the type of standards set by each agency (e.g., the Department of Agriculture sets standards for food and farm products, including tobacco). Toth (1996) provided data on whether the agency audits or certifies entities governed by its standards. We examined the websites and/or the standards to determine whether the agency provides a minimum standard (pass/fail) or a series of grades (e.g., beef grades provided by the U.S. Department of Agriculture).

In the sample of 64,53 of the federal agencies (83\%) set only minimum (i.e., pass/fail) standards. The other eleven agencies $(17 \%)$ issue a range of grades to differentiate the quality of goods. Since many of these agencies are not able to create an effective enforcement and deterrence regime (see Law 2006), they set quality/grading standards to induce entities to use better ingredients, production methods, and accurate labels. Given chronic complaints about under-funding of the Securities and Exchange Commission (although its budget was doubled after the Sarbanes-Oxley Act of 2002), one might also expect to observe graded reporting standards in financial markets. Such grades exist for ratings of bonds and insurance, but not for financial reports. Of the three predictions of the DG model, all government agencies are consistent with one (setting an absolute level for a passing grade), and most are not consistent with the other two (a grading system of intermediate level of fineness, and an elite grade). The U.S. Department of Agriculture, with its hierarchy of grades for foods and grains including elite grades (e.g., U.S. Prime beef), is an exception, in that is consistent with all three DG predictions for optimal grading systems.

Some government agencies have experimented with more detail than pass/fail reports. For example, California changed its restaurant hygiene reporting system from pass/fail to a letter grade system. Presently, a score of $90-100 \%$ is A, $80-89 \%$ is B, $70-79 \%$ is C, and a score from $60-70 \%$ is reported as a number. Two consecutive ratings with a score below $60 \%$ is an $\mathrm{F}$ and the restaurant can be shut down for failing the inspection. All restaurants are required by law to post these grades in a prominent place, where they can be easily seen by consumers. A field study by Jin and Leslie (2003) documented a shift in consumption patterns, with restaurants graded A reporting a significant increase in sales while those rated $\mathrm{C}$ or lower reported decreases. They also documented a significant decrease in visits to doctors and hospitals for food-related illnesses after the change in hygiene reports, suggesting that the change in grading scheme improved the hygiene of California restaurants.

Private-sector standards and seals exhibit greater variability. The certification of electrical appliances by Underwriters Laboratory is an example of a pass/fail standard, whereas TRUSTe's use of a specific seal signifying compliance with laws relating to children exemplifies the use of multiple seals to signal different levels of e-commerce privacy (JMS 2003, 2005). Alternatively, baseball cards are graded on a 10 -point rating scale, whereas Consumer Reports employs a 100-point scale in rating automobiles, and the $\mathrm{ELO}^{6}$ ratings for chess players are calculated according to a 3,000-point scale. In private markets, rival standard-setting organizations compete by differentiating themselves along a variety of dimensions, including the fineness of reports and the certification processes employed (JMS 2003). Some organizations let consumers choose the fineness and detail in the report for a price. Alternatively, consumers can sometimes buy different levels of detail from rival certification

${ }^{6}$ It is not clear if ELO has an upper limit; the maximum rating ever assigned to a player has been 2851. 
agencies, as when a consumer who wants to buy a toaster can get a pass/fail report from Underwriters Laboratories, or get a more detailed (finer) report from Consumers Reports.

Press reports indicate that the credit ratings firm Moody's has developed a new line of business to certify the internal control systems of hedge funds, using a report based on a five point scale (e.g., Tergesen, 2005). In September 2006, Soring Capital was the first hedge fund to be rated by Moody's, receiving a rating of 4. Moody's markets the service to hedge-fund clients, who will pay for the rating service just as companies pay their auditors. Morningstar may also offer a similar internal control rating service, but plans to charge investors directly for its reports and thus hopes to be more independent of the hedge-fund management (Tergesen 2005). ${ }^{7}$

\section{An Illustrative Example: Baseball Card Certification}

We chose the unregulated online baseball card certification market for a more detailed examination of certification reports, because it is a competitive certification market where twenty three certification agencies compete in an online environment (Jamal and Sunder 2011). Grading schemes used by 23 baseball card certification services are shown in Table 3.

Professional Sports Authenticator (PSA) started providing an online grading service in 1991 and currently dominates the market in volume. PSA rates cards on a 10 -point scale at 1 point intervals (e.g., 8, 9, and 10). Each point on the scale also has a qualitative label (e.g., $10=$ mint). PSA does not use a curve to grade, and does not create a super elite grade (the top grade of 10 is given to about $10 \%$ of cards graded). Without an elite grade, PSA's practice is consistent with two of the three predictions (intermediate fineness, absolute grade cut-offs) of the DG model.

Starting in 1999, the privately-held Beckett Grading Service (BGS) has gained a significant share of the market and emerged as PSA's main competitor. BGS distinguishes itself from PSA in three ways: First, it uses a 10 -point scale with 0.5 point increments, and provides sub-grades for centering, corners, edges, and surfaces. Second, it uses a stricter grading standard, giving the highest grade of 10 to less than $0.1 \%$ of the cards it grades. It builds market awareness of BGS's grading strictness by periodically posting the distribution of grades it has issued (the BGS distribution is available to its customers at http://www.beckett.com/grading/popreport.asp?action=summary). Third, BGS caters to different market segments by offering three brands of service at different prices: a standard BGS service, an elite vintage service (BVG), and a value product for more price-conscious customers (BCCG). BGS's ratings activities are consistent with all three predictions of the DG model. ${ }^{8}$

The third major online rater of baseball cards, far behind the two leaders, is Sportscard Guaranty Corporation (SGC). It entered this market in 1999 and attempted to distinguish itself by introducing a 100-point scale. SGC later provided a nonlinear conversion table to translate its 100 -point scores into a 10-point score with the associated qualitative labels. SGC does not provide additional subgrades. This finding is consistent with observations by Krislov (1997), who provides several examples where countries (and companies) use incompatible standards to differentiate their products from

\footnotetext{
7 Klein (1997) models the determinants of whether the buyer or the seller should pay for certification. The competition between Moody's and Morningstar may provide an interesting opportunity to test the implications of Klein's model. In the audit literature, some preliminary evidence about having investors pay directly for audit services has been provided by Mayhew and Pike (2004).

8 Publication of the empirical distribution of grades could indirectly set a "norm" of what grades should be, even if the formal grading scheme does not require the use of a grading curve. Publication may also influence the quality of cards offered for grading to a service, and thus change the substantive implications of a fixed grade distribution.
} 


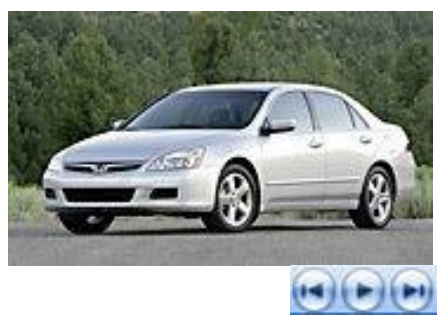

MSRP Price Range

Invoice Price Range

MSN Ratings

Expert

$\underline{8.0}$

Price it with Options
$\$ 18,225-\$ 29,400$

$\$ 16,412$ - $\$ 26,455$

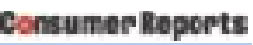

Overall Test Score

$\underline{89}$ Read Snapshot

Save this Car

\section{BensumerReports org}

Ratings Snapshot

2006 Honda Accord EX V6

Other Trims Tested

- EX 4-cyl

\section{Consumer Report Overview}

Highs: Accelertion, ride, andling, driving position, front-seat comfort, controls, crash-ts results.

Lows: Road noise.

The Accord V6 is our top-rated family sedan. It has fairly agile handling, and the ride is steady and compliant. Inside the car the Accord is roomy, quiet and refined, although some road noise is noticeable. A telescoping steering column allows drivers to find an ideal position. The automatic shifts very smoothly and responsively. The four-cylinder engine is smoother than many V6s. Side and curtain air bags are standard. The V6 model is very quick and relatively fuel efficient. V6 models also get standard stability control for 2006. The V6 hybrid version is even quicker and gets 25 mpg overall, just one mpg better than the four-cylinder, which may not justify its $\$ \mathbf{3 0 , 0 0 0}$ price tag. Crash-test results are impressive.

\section{Road Test Results \\ Acceleration \\ Accident avoidance \\ Comfort and convenience \\ Realworld fuel economy

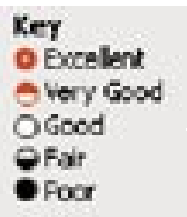 \\ For 20 more ratings and the \\ Consumer Reports \\ Bottom Line \\ Price on this model, click here.}

Overall Rating

(Family sedans)

\begin{tabular}{l|l|l|l|l}
$P$ & $F$ & $G$ & VG &
\end{tabular}

Highest
Rated

EX V6 89

Lowest Rated 35 
Table 3: Sports Card Grading Services

\begin{tabular}{|c|c|c|c|c|c|}
\hline Name & $\begin{array}{c}\text { Year } \\
\text { Founded }\end{array}$ & $\begin{array}{l}\text { \# of } \\
\text { Grades } \\
\text { Issued }\end{array}$ & $\begin{array}{c}\text { Grade on } \\
\text { a } \\
\text { Curve }\end{array}$ & $\begin{array}{l}\text { Super Elite } \\
\text { Grade }\end{array}$ & Other Features \\
\hline 1. Accugrade (ASA) & 1988 & 13 & $\mathrm{No}_{\mathrm{O}}$ & No & Invented 10-point scale (1-10) \\
\hline $\begin{array}{l}\text { 2. Professional Sports } \\
\text { Authentication } \\
\text { (PSA) }\end{array}$ & 1991 & 10 & No & No & $\begin{array}{l}\text { Standard } 10 \text { point scale }(8,9,10) \\
\text { Uses qualitative labels (e.g., } 10= \\
\text { mint condition) }\end{array}$ \\
\hline 3. KSA & 1996 & 14 & No & Yes & $\begin{array}{l}\text { Some grades rise in increments of } 0.5 \\
(\text { e.g. } 9,9.5,10)\end{array}$ \\
\hline $\begin{array}{l}\text { 4. American Authentication } \\
\text { (AAI) }\end{array}$ & 1996 & 10 & No & No & Standard 10 point scale $(8,9,10)$ \\
\hline 5. Finest Grading (FGS) & 1997 & 14 & No & Yes & Standard 10 point scale $(8,9,10)$ \\
\hline 6. Map Industries & 1998 & 14 & No & Yes & uses $10+$ to designate elite grade \\
\hline $\begin{array}{l}\text { 7. Beckett Grading Service } \\
\text { (BGS) } \\
\text {-Vintage Grading (BVG) } \\
\text {-Collectors Club (BCCG) } \\
\end{array}$ & 1999 & 19 & No & Yes & $\begin{array}{l}\text { Grade increase in increments of } 0.5 \\
(8,8.5,9,9.5) \\
\text { Sub-grades given for corners, } \\
\text { centering, edges and surfaces }\end{array}$ \\
\hline $\begin{array}{l}\text { 8. Sportscard Guaranty } \\
\text { (SGC) }\end{array}$ & 1999 & $100 / 18$ & No & Yes & $\begin{array}{l}\text { Started with } 100 \text {-point scale } \\
\text { Later created conversion metric to } \\
10 \text { point scale with some } 0.5 \text { grade } \\
\text { increments }\end{array}$ \\
\hline$\overline{\text { 9. The Final Authority (TFA) }}$ & 1999 & 19 & No & Yes & $\begin{array}{l}10 \text { point scale with grades increasing } \\
\text { in } 0.5 \text { units }\end{array}$ \\
\hline 10. Collection Monster (CM) & 1999 & 19 & No & Yes & $\begin{array}{l}10 \text { point scale with grades increasing } \\
\text { in } 0.5 \text { units }\end{array}$ \\
\hline $\begin{array}{l}\text { 11. Advanced Grading } \\
\text { (AGS) }\end{array}$ & 2000 & 11 & No & Yes & $\begin{array}{l}10 \text { point scale with one } 0.5 \text { unit } \\
\text { grade }(9.5)\end{array}$ \\
\hline 12. Mint Grading Services & 2000 & 18 & No & Yes & $\begin{array}{l}10 \text { point scale with grades increasing } \\
\text { in } 0.5 \text { units (but no } 9.5 \text { grade) }\end{array}$ \\
\hline 13. CTA Grading Experts & 2000 & 11 & No & Yes & $\begin{array}{l}10 \text { point scale with one additional } \\
\text { elite grade }\end{array}$ \\
\hline $\begin{array}{l}\text { 14. Bear Stats Grading } \\
\text { (BSGS) }\end{array}$ & 2002 & 14 & No & Yes & $\begin{array}{l}10 \text { point scale with some grades } \\
\text { increasing in } 0.5 \text { units }\end{array}$ \\
\hline $\begin{array}{l}\text { 15. Global Authentication } \\
\text { (GAI) }\end{array}$ & 2002 & 19 & No & Yes & $\begin{array}{l}10 \text { point scale with grades increasing } \\
\text { in } 0.5 \text { units }\end{array}$ \\
\hline $\begin{array}{l}\text { 16. Pro Sports Grading } \\
\text { (PRO) }\end{array}$ & --- & 22 & No & Yes & $\begin{array}{l}10 \text { point scale with grades increasing } \\
\text { in } 0.5 \text { units (and a } 9.8 \text { grade) }\end{array}$ \\
\hline $\begin{array}{l}\text { 17. Professional Grading } \\
\text { Service (PGS) }\end{array}$ & --- & 19 & No & Yes & $\begin{array}{l}10 \text { point scale with grades increasing } \\
\text { in } 0.5 \text { units }\end{array}$ \\
\hline $\begin{array}{l}\text { 18. World Class Grading } \\
\text { (WCG) }\end{array}$ & --- & 20 & No & Yes & $\begin{array}{l}10 \text { point scale with grades increasing } \\
\text { in } 0.5 \text { units (includes an elite } 10^{*} \\
\text { grade) }\end{array}$ \\
\hline $\begin{array}{l}\text { 19. Champs Grading Service } \\
\text { (CGS) }\end{array}$ & --- & 10 & No & No & Standard 10 point scale $(8,9,10)$ \\
\hline 20. Grade Tech & --- & 21 & No & Yes & $\begin{array}{l}10 \text { point scale with grades increasing } \\
\text { in } 0.5 \text { units }\end{array}$ \\
\hline 21. Premier Grading (PGI) & --- & 20 & No & Yes & $\begin{array}{l}10 \text { point scale with grades increasing } \\
\text { in } 0.5 \text { units (and a } 9.8 \text { grade) }\end{array}$ \\
\hline $\begin{array}{l}\text { 22. Gem Trading } \\
\text { - Gem Elite }\end{array}$ & --- & $9 / 18$ & No & Yes & $\begin{array}{l}\text { Grades from } 2-9 \text { with more precision } \\
\text { provided ( } 0.5 \text { increments) if client } \\
\text { pays more }\end{array}$ \\
\hline $\begin{array}{l}\text { 23. Sports Memorabilia } \\
\text { Authenticator (SMA) }\end{array}$ & --- & 19 & No & Yes & $\begin{array}{l}10 \text { point scale with grades increasing } \\
\text { in } 0.5 \text { units }\end{array}$ \\
\hline
\end{tabular}

Note: We visited 23 sports card grading services online to identify the year of formation, and the rating scales. They use a 10 -point scale with 1 or $1 / 2$ point increments; some use $+s$ or have discontinuities in their scale (e.g., do not award some grades such as 9.5 ). 
those of their rivals. The problems SGC faced in introducing a 100-point scale are consistent with DG's prediction that high levels of fineness are suboptimal, due to measurement and interpretation errors.

Twenty other baseball card certification services vie for customers using the 10-point scale in increments of 1 or 0.5 , some adding extra grade categories (e.g. pristine), thus allowing some 10-22 possible grades. The creation of extra elite grades is consistent with DG's prediction. None of these twenty sites uses a grading curve, and all have a reporting scheme of intermediate fineness. Overall, 19 out of the 23 sportscard certification agencies (83\%) issue an elite grade which is consistent with the DG model. Contrary to the usual preference in accounting for the standardization of reports, we observe competing certification agencies introducing small variations in their grading schemes (increments of 1 or 0.5 points, use of qualitative labels, 10-21 possible grades, and even a 100 point scale in one case) as they use the report to differentiate themselves from their competitors. (See Krislov 1997 for a detailed analysis of deliberately introducing incompatible standards across countries and competitors). In contrast to the government agencies, the practices of the twenty three private baseball card graders generally conform to the DG predictions.

In private, unregulated markets, the same organization often supplies both a set of standards and a certification service (see JMS for a description of competition in the e-commerce privacy market). This results in competition among standards-certification bundles. Certification services may also be provided by third parties licensed by the standard-setter (e.g., ISO certification). Certifiers of private goods such as automobiles, wines, and baseball cards also develop reporting standards, often using scales of varying fineness. While this notion of bundling standard setting and certification may seem novel to accountants today, in the pre-SEC era individual accounting firms often initiated both accounting and auditing innovations. For example, the 1902 audit of U.S. Steel by Price Waterhouse prompted the development of consolidated financial statements, as well as the long-form audit report (Vangermeersch 1986).

For many goods and services, information aggregators (e.g., MSN Auto, at http:// autos.msn.com) create composite reports from ratings provided by multiple certifiers (see Figure 1). The MSN Auto report on the Honda Accord, for example, provides an average of ratings from MSN's designated experts; the individual reports from each expert, on a 10-point scale; a user rating from volunteer members of the public; and an excerpt of an independent expert opinion from the Consumer Reports based on a 100-point scale. The Consumer Reports excerpt also provides sub-ratings for acceleration, accident avoidance, comfort and convenience, on-the-road fuel economy (all on a five-point scale), and a qualitative discussion of the car.

Similarly, an information aggregator for wines, www.vintages.com, tabulates ratings of listed wines by Robert Parker Jr. and James Sucking, both using a 100-point scale; Jancis Robinson, who uses a 20 -point scale; Tom Wilson, using a 10-point scale; and Shari-Mogk-Edwards, employing a 5-point scale). In addition, qualitative comments from one or more of these experts are included. There is little evidence of consumers being confused by the provision of multiple assessments on varying scales.

\section{Implications for Auditing}

Auditing standards currently require a public report which is essentially no more nuanced than a pass/fail report. The size of the audit firm, care in client selection, and the monitoring of compliance 
with GAAP may be the basis of an auditor's reputation (see the Price Waterhouse audit fee premium reported in Simunic, 1980). Given that a major objective of the Sarbanes-Oxley Act is to convey information to shareholders about internal controls (currently provided as a pass/fail certificate), a graded audit report with sub-grades for internal controls, governance, quality of accounting methods, and quality of disclosure may be more useful to the shareholders.

In the pre-1930s unregulated era, audit firms issued either a short- or a long-form report (Brief 1987). The short-form report had a standardized, pass/fail format of the type used currently, but could be as short as a single word ("Certified"), a line ("I certify the above statement is correct"), or a paragraph (Himmelblau 1927, pp. 12-15). The long-form reports included comments on the propriety of accounting methods, descriptions of audit procedures carried out, and occasional representations about the market values of certain current assets as being in excess of cost. The text of long-form reports was client-specific and varied for the same client over time (Himmelblau 1927). The 1902 Price Waterhouse report on U.S. Steel set a new standard by providing additional information on valuation issues, such as fixed asset capitalization policy and depreciation, inventory valuation, revenue recognition, and audit procedures conducted to verify cash (Vangermeersch, 1986, P. 24).

A century later, the richness and detail of these reports has been replaced by boilerplate text which conveys little of the auditor's detailed knowledge to the reader. One can argue that such knowledge could be of use to shareholder and board decisions. The standard pass/fail report is closer to the practices of government agencies, and is a departure from the finer reports suggested by the DG model as well as from the dominant practice of private certifiers. ${ }^{9}$ Regulation of auditing sets a floor on the precision of audit reports, and the behaviour of audit firms does not indicate that they are aiming any higher.

\section{Conclusion}

We report evidence that certification services are widely available in unregulated private goods and services markets, including certification by experts who base their opinion on formal written standards, experts who do not use formal standards, laypersons' opinions, and meters that record activity (e.g., number of books sold). Power's $(1994$; 1999) findings on the demand for audit in the public sector are corroborated; the phenomenon of "audit explosion" also pervades the private sector. In some new markets such as WebTrust, accounting firms failed in competing with non-traditional certifiers who use very different business models. Our results suggest that these non-traditional competitors have better privacy standards and their clients have better privacy practices than the clients of accounting firms. The domain of accountant-provided assurance may be narrower than that envisaged by the AICPA, and accountants may need to stay closer to traditional accounting markets to be successful. Likewise, formal professional credentials and government connections may not give accountants much leverage in private, unregulated markets. Accountants may not have the skills and business models to become certifiers of other goods and services in the economy.

Second, we examine the fineness of certification by government agencies and private certification

\footnotetext{
${ }_{9}$ Implementation issues such as legal liability are beyond the scope of this paper (see Bush et al., 2006). These issues can be dealt with by providing a safe harbor, providing these reports only to the audit committee (and not directly to investors), or by creating a grading standard like that for U.S. Prime beef and then providing a certification for companies who have high quality financial reporting.
} 
services. Government agencies usually issue pass/fail reports. Private certification reports use a finer scale $(5,10$, or 10 points) and often include some qualitative commentary and sub-scales, breaking down the overall rating into various sub-components. Often, multiple certification reports are available for the same product. The pass/fail scheme in the boilerplate format of financial audit reports appears to be driven by their mandated demand, and is focused on preventing litigation rather than providing information for decision making by shareholders and others. The recent appearance of voluntarily provided, graded reports on the quality of internal control of hedge funds by Moody's suggests that the lifting of the mandatory requirement may give rise to demand for finer gradations in financial audit reports too.

The current study looks at unregulated markets for the certification of goods and services in order to draw implications for the accountants. Since audit firms have to perform a complicated legitimating process without much leverage from their traditional networks to be successful in these unregulated markets, more research is needed on how audit firms may have to change to meet competitive challenges as they enter new certification markets. One possibility is that auditors could issue more detailed and firm-specific reports for certification services provided in unregulated markets (such a sustainability audits). Our results suggest that audit regulators should consider allowing auditors to experiment with offering more detailed audit reports.

\section{REFERENCES}

ANTLE, R. 1982. The auditor as an economic agent. Journal of Accounting Research 20 (Autumn): 1-20.

BRIEF, R. 1987. Corporate financial reporting at the turn of the century. Journal of Accountancy (Centennial Issue) (May): 142-157.

BUSH, T., S. FEARNLEY, AND S. SUNDER. 2006. Auditor liability reforms in UK and US: Who benefits? First Draft, April 19.

COOPER, D.J., AND K. ROBSON. 2006. Accounting, professions and regulation: Locating the sites of professionalization. Accounting, Organizations and Society 31 (July/August) : 415-444.

Covaleski, M.A., M.W. DiRsmith, AND L. RitTEnBERG. 2003. Jurisdictional disputes over professional work: The institutionalization of the global knowledge expert. Accounting, Organizations and Society 28 (May) : 323-355.

DEANGELO, L. 1981. Auditor size and audit quality. Journal of Accounting and Economics 3 (December): 183-199.

DUBEY, P., AND J. GEANAKOPLOS. 2010. Grading exams: 100, 99 ...,1 or A,B,C? Incentives in games of status. Games and Economic Behavior 69 (May): 72-94.

ELLIOTT, R. K. 1995. Professional growth through new assurance services. Report of the Chairman of the AICPA Special Committee on Assurance Services to AICPA Council, The American Institute of Certified Public Accountants (AICPA).

ELLIOTT, R.K. 1998. Assurance services and the audit heritage auditing. Auditing : A Journal of Practice E Theory 12: 1-7.

GENDRON, Y., AND M. BARRETT. 2004. Professionalization in action: Accountants' attempt at building a network of support for the WebTrust seal of assurance. Contemporary Accounting Research 21 (Fall) : 563-602.

GENDRON, Y., D.J. COOPER, AND B. TOWNLEY. 2007. The construction of auditing expertise in measuring government performance. Accounting, Organizations and Society 32 (January/February) : 101-129.

HimmelblaU, D. 1927. Auditors' Certificates. New York, NY : The Ronald Press Company.

JAMAL, K., M. MAIER, AND S. SUNDER. 2003. Privacy in e-commerce: Development of reporting standards, disclosure, and assurance services in an unregulated market. Journal of Accounting Research 41 (2003) : 285-309.

JAMAL, K., M. MAIER, AND S. SUNDER. 2005. Enforced standards versus evolution by general acceptance: A comparative study of e-commerce privacy disclosure and practice in the U.S. and the U.K. Journal of Accounting Research 43 (March) : 73-96.

JAMAL, K., AND S. SUNDER. 2011. Is mandated independence necessary for audit quality? Accounting, Organizations and Society 36 (May/July): 284-292.

JIN, G., AND P. LESLIE. 2003. The effects of information on product quality: Evidence from restaurant hygiene grade cards. The Quarterly Journal of Economics 118 (May) : 409-451.

KLEIN, D. B. 1997. Trust for hire: Voluntary remedies for quality and safety. In: KLEIN, D. B. Reputation: Studies in The Voluntary Elicitation of Good Conduct. Ann Arbour, MI. University of Michigan Press.

KRISLOV, S. 1997. How Nations Choose Product Standards and Standards Change Nations. Pittsburgh, PA : University of Pittsburgh Press.

LAW, M.T. 2006. How do regulators regulate? Enforcement of the Pure Food and Drugs Act, 1907-38. The Journal of Law, 
Economics and Organization 22 (October) : 459-489.

LIZZERI, A. 1999. Information revelation and certification intermediaries. The Rand Journal of Economics 30 (Summer): $214-231$.

MENNICKEN, A. 2010. From inspection to auditing: Audit and markets as linked ecologies. Accounting, Organizations and Society 35 (April) : 334-359.

POWER, M. 1994. The Audit Explosion. London, UK : Demos.

POWER, M. 1999. The Audit Society: Rituals of Verification. New York, NY : Oxford University Press.

RADCLIFFE, V.S. 1998. Efficiency audit: An assembly of rationalities and programmes. Accounting, Organizations and Society 23 (May) : 377-410.

SIMUNIC, D.A. 1980. The pricing of audit services: Theory and evidence. Journal of Accounting Research 18 (Spring): 161-190.

TERGESEN, A. 2005. Sizing up a hedge. BusinessWeek Online, November 28.

TOTH, R. B. 1996. Standards Activities of Organizations in the United States (NIST Special Publication 806). Gaithersburg, MD : U. S. Department of Commerce, National Institute of Standards and Technology (NIST).

VANGERMEERSCH, R. 1986. Financial Reporting Milestones in the Annual Reports of United States Steel Corporation. New York, NY : Garland Publishing. 